\title{
Coliform and Metal Contamination in Lago de Colina, a Recreational Water Body in Chihuahua State, Mexico
}

\author{
Hector Rubio-Arias ${ }^{1}{ }^{*}$, Nora I. Rey ${ }^{2}$, Rey M. Quintana ${ }^{1}$, G. Virginia Nevarez ${ }^{1}$ and \\ Oskar Palacios ${ }^{2}$
}

1 Autonomous University of Chihuahua, Periferico Francisco R. Almada, Km. 1 Colonia Zootecnia, Chihuahua, Chih. C.P. 31000, Mexico; E-Mails: rquintan@uach.mx (R.M.Q.); vnevare@uach.mx (G.V.N.)

2 Department of Natural Resources, College of Zoo-technology and Ecology, Autonomous University of Chihuahua, Periferico Francisco R. Almada, Km. 1 Colonia Zootecnia, Chihuahua, Chih. C.P.31453, Mexico; E-Mails: ivet_rey77@ hotmail.com (N.I.R.); opalacios@hotmail.com (O.P.)

* Author to whom correspondence should be addressed; E-Mail: rubioa1105@ hotmail.com; Tel.: +52-614-4137157; Fax: +52-614-4340303.

Received: 23 November 2010; in revised form: 22 February 2011 / Accepted: 24 February 2011 / Published: 23 June 2011

\begin{abstract}
Lago de Colina (Colina Lake) is located about $180 \mathrm{~km}$ south of the city of Chihuahua (Mexico), and during the Semana Santa (Holy Week) vacation period its recreational use is high. The objective of this study was to quantify coliform and heavy metal levels in this water body before and after the Holy Week vacation period in 2010 . Twenty sampling points were randomly selected and two water samples were collected at each point near the surface $(0.30 \mathrm{~m})$ and at $1 \mathrm{~m}$ depth. After the Holy Week vacation the same twenty points were sampled at the same depths. Therefore, a total 80 water samples were analyzed for fecal and total coliforms and levels of the following metals: Al, As, B, Ca, $\mathrm{Cr}, \mathrm{Cu}, \mathrm{Fe}, \mathrm{K}, \mathrm{Mg}, \mathrm{Mn}, \mathrm{Na}, \mathrm{Ni}, \mathrm{Pb}, \mathrm{Se}, \mathrm{Si}$ and $\mathrm{Zn}$. It was hypothesized that domestic tourism contaminated this water body, and as a consequence, could have a negative impact on visitor health. An analysis of variance (ANOVA) study was performed for each element and its interactions considering a factorial design where factor A was sample date and factor B was sample depth. Fecal coliforms were only detected at eight sampling points in the first week, but after Holy Week, both fecal and total coliforms were detected at most sampling
\end{abstract}


points. The concentrations of $\mathrm{Al}, \mathrm{B}, \mathrm{Na}, \mathrm{Ni}$ and Se were only statistically different for factor A. The levels of $\mathrm{Cr}, \mathrm{Cu}, \mathrm{K}$ and $\mathrm{Mg}$ was different for both date and depth, but the dual factor interaction was not significant. The amount of $\mathrm{Ca}$ and $\mathrm{Zn}$ was statistically different due to date, depth and their interaction. No significant differences were found for any factor or the interaction for the elements $\mathrm{As}, \mathrm{Fe}$ and $\mathrm{Mn}$. Because of the consistent results, it is concluded that local tourism is contaminating the recreational area of Colina Lake, Chihuahua, Mexico.

Keywords: heavy metals; pollution; body water; recreational areas; Chihuahua; Mexico

\section{Introduction}

The Mexican government is beginning to promote domestic tourism throughout Mexico as a means to generate new jobs and to improve local economies. One of the main problems in the Mexican beaches or coastal areas used as recreational areas is the level of water contamination [1-3]. Mexico's economy as a whole depends largely on international tourism, especially in those areas which have recreational beaches. However, in rural areas it is difficult to promote this sort of tourism; therefore, domestic tourism should be incentivized. The problem is aggravated in Mexican states that do not have good aquatic resources or where access to aquatic recreational areas is difficult and expensive.

Chihuahua is the largest state in Mexico and is located in the north central region, just south of the US-Mexico border. The overall environment in Chihuahua is arid or semi-arid and, as a consequence, there are few aquatic resources, making it difficult to promote local tourism because it is generally well known that mountain scenarios rank second after coastal regions as popular tourist destinations [4]. Colina Lake is a man-made water reservoir where local inhabitants depend on domestic tourism that comes mostly from the city of Chihuahua, which has about one million inhabitants. Moreover, Chihuahua's stakeholders depend on Colina Lake for commercial purposes and fishing activities, as well as for recreational purposes. For example, it is estimated that during the Semana Santa (Holy Week) period the lake receives 25,000 to 30,000 visitors [5]. Holy Week is a religious-based festivity that lasts one week and extends to all Mexico. It is important to point out that Chihuahua's tourism department and other local agencies have aggressively promoted Colina Lake as a recreational destination.

After the Holy Week vacation period, the lake is notorious for having large amounts of trash in the area, and reception of discharged domestic wastewaters and solid waste dumping and therefore, we hypothesized that the water would be contaminated, creating a dangerous conditions for visitors as well as for the local inhabitants in the Colina Lake area and that consequently the viability of the recreational center might be in jeopardy. Consequently, the objective of this study was to quantify fecal and heavy metal levels in the water of the Colina Lake before and after the Holy Week vacation period. These results will be important for the different levels of Chihuahua's authorities to promote future conservation actions for this aquatic resource to have a clean environment; otherwise it will be undermined as one of the state's major economic tourist forces. 


\section{Materials and Methods}

The study was conducted during 2010 and carried out at Lago de Colina (Colina Lake) located in the municipality of San Francisco de Conchos of the State of Chihuahua, Mexico (Figure 1). This

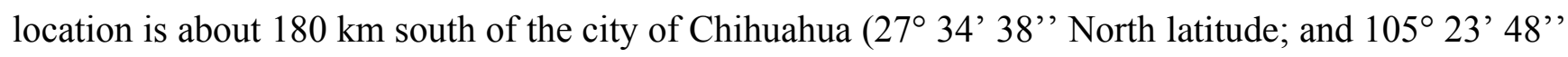
West longitude), and the lake is about $3 \mathrm{~km}$ wide and $8 \mathrm{~km}$ long. The main water source is the Conchos River and the lake's depth is $25-35 \mathrm{~m}$. This water reservoir is a man-made lake resulting from the impoundment of the Conchos River by the La Boquilla dam, and is considered the biggest one in Chihuahua, with a capacity of $2,895 \mathrm{Mm}^{3}$ [6]. The maximum ambient temperature is $41.7^{\circ} \mathrm{C}$, and the minimum is $14.1{ }^{\circ} \mathrm{C}$. Average annual precipitation is $363 \mathrm{~mm}$. and the dam is about 1,250 meters above sea level. The lake was divided using satellite imagery and then 20 sampling locations were randomly selected and properly georeferenced. The 20 locations were sampled on March 21 before the Holy Week vacation period of 2010 and then the same locations were sampled again on April 15 after the vacation period. At each point, four water samples were obtained - two in the top $0.30 \mathrm{~m}$ and two at $1.0 \mathrm{~m}$ depth. Of the two top samples, one was used to quantify coliform presence and the other was used to measure physico-chemical and metal level variables. The same was done with the two samples obtained at 1.0 depth. The water samples were obtained following procedures established in the Mexican norm NMX-AA-014-1980 [7].

Figure 1. Map showing Mexico, the State of Chihuahua and the sampling points around Colina Lake.

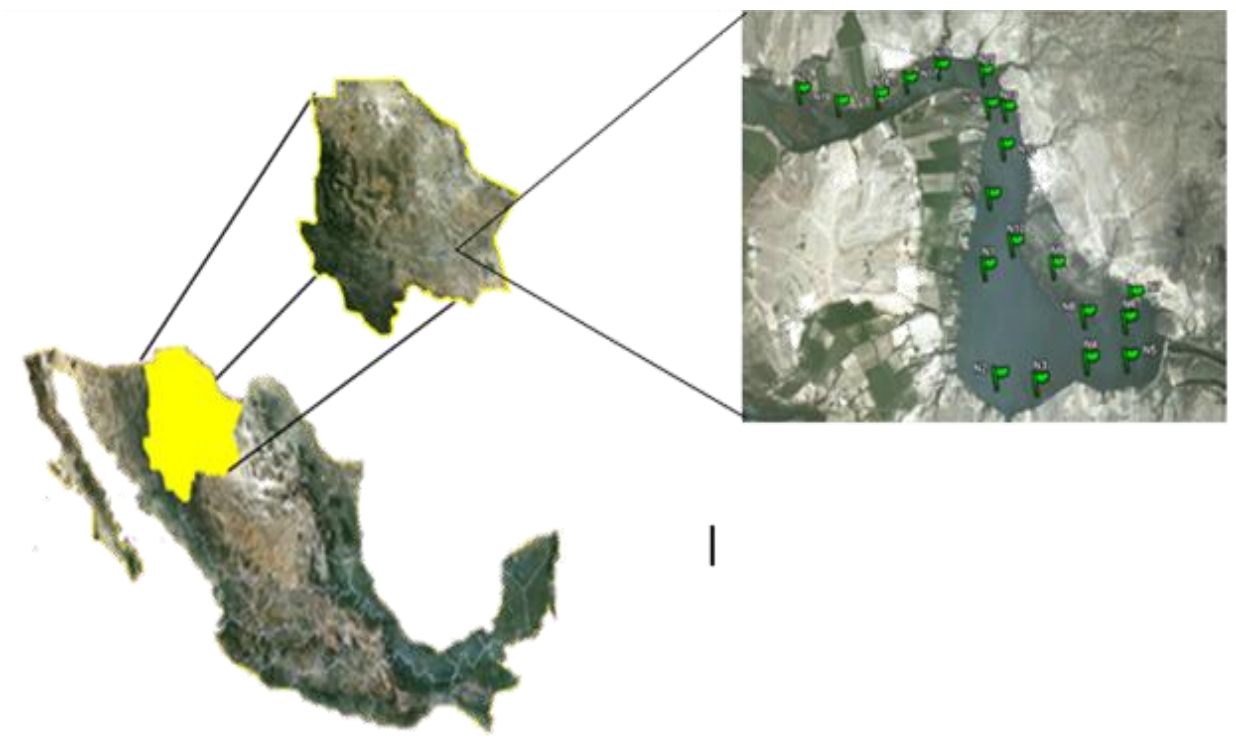

Temperature, $\mathrm{pH}$ and electrical conductivity (EC) values were determined in situ. The temperature was recorded using a mercury thermometer according to the Mexican norm NMX-AA-007-SCF [8]. The $\mathrm{pH}$ was measured with a Hanna Waterproof $\mathrm{pH} / \mathrm{EC} / \mathrm{Temp}$ potentiometer instrument according to the Mexican norm NMX-AA-008-SCF [9]. The EC was obtained with the same device used to determine the $\mathrm{pH}$ according to the Mexican norm NMX-AA-093-SCF [10]. The water samples were collected in $1 \mathrm{~L}$ sterilized containers and properly preserved in a cool place $\left(4^{\circ} \mathrm{C}\right)$. Immediately after the water sample was obtained, a $1 \mathrm{~L}$ sample was transported to the laboratory of the College of Chemistry of the Autonomous University of Chihuahua to evaluate total and fecal coliforms. The other 
$1 \mathrm{~L}$ samples were transported to the laboratory of the Faculty of Zootechnology and Ecology of the Autonomous University of Chihuahua for further analysis.

The evaluated metals were: aluminum (Al), arsenic (As), boron (B), calcium (Ca), chromium $(\mathrm{Cr})$, copper $(\mathrm{Cu})$, iron $(\mathrm{Fe})$, potassium $(\mathrm{K})$, magnesium $(\mathrm{Mg})$, manganese $(\mathrm{Mn})$, sodium $(\mathrm{Na})$, nickel $(\mathrm{Ni})$, lead $(\mathrm{Pb})$, selenium $(\mathrm{Se})$, silicon $(\mathrm{Si})$ and zinc $(\mathrm{Zn})$. Metals were quantified using a Perkin Elmer 2100 Inductively Coupled Plasma-Optical Emission Spectrometer (ICP-OES) property of La Campana Experimental Station (which is part of the Mexican National Research Institute for Forestry, Agriculture and Animal Production) after a sample digestion performed according to the Mexican norm NMX-AA-051-SCFI [11] as follows: a portion of each sample (100 mL) was filtered using a Whatman filter paper and digested completely with $5 \mathrm{~mL}$ of concentrated $\mathrm{HNO}_{3}$. For the quantification of the different elements, standards of known concentrations were prepared for each one, followed by suitable calibration of the wavelength, plasma position and gas flux. The fecal and total coliforms were quantified according to the following procedure: a $100 \mathrm{~mL}$ water sample was filtered through a $0.45 \mu \mathrm{m}$ porosity membrane utilizing a Kitasato flask connected to a vacuum system. The sample was then placed in red-violet agar (RVA) for contact of the membrane with the agar plat and the samples were then incubated for $24 \mathrm{~h}$ at $35 \pm 0.5^{\circ} \mathrm{C}$ for total coliforms and $44.5^{\circ} \mathrm{C}$ for fecal coliforms. Finally, Colony Forming Units (CFU) per $100 \mathrm{~mL}$ of water were counted [12]. All tests were done in duplicate. The sample means of coliforms were then transformed to logarithmic units (log) to compare the results with those established in the Mexican Norm NOM 112-SSA1-1994 [13].

\section{Results and Discussion}

In general, there were no significant differences in water samples concerning $\mathrm{pH}$, temperature and electrical conductivity. Nevertheless, an increase in these parameters was noted after the Holy Week vacation period (Table 1).

Table 1. Means and descriptive statistics of the parameters $\mathrm{pH}$, temperature and $\mathrm{EC}$ of

Colina Lake before and after the Holy Week vacation period.

\begin{tabular}{|c|c|c|c|c|c|c|c|}
\hline & & & Before & & & After & \\
\hline Parameter & Depth (m) & Mean & SEmean & StDev & Mean & SEmean & StDev \\
\hline $\mathrm{pH}$ & 0.30 & 8.50 & 0.018 & 0.084 & 8.61 & 0.015 & 0.069 \\
\hline & 1.0 & 8.53 & 0.023 & 0.103 & 8.56 & 0.028 & 0.127 \\
\hline $\begin{array}{c}\text { Temperature } \\
\left({ }^{\circ} \mathrm{C}\right)\end{array}$ & 0.30 & 12.80 & 0.119 & 0.532 & 18.11 & 0.171 & 0.763 \\
\hline & 1.0 & 12.16 & 0.199 & 0.889 & 17.75 & 0.190 & 0.851 \\
\hline $\mathrm{EC}\left(\mathrm{dSm}^{-1}\right)$ & 0.30 & 208 & 1.380 & 6.160 & 228.5 & 3.420 & 15.31 \\
\hline & 1.0 & 208 & 1.170 & 5.230 & 226.0 & 1.520 & 6.81 \\
\hline
\end{tabular}

Over $22 \%$ of the water samples tested positive for total coliforms before the Holy Week vacation sampling period (Table 2 format all tables the same way). It is important to point out that no fecal coliforms were detected in any water sample before the Holy Week sampling. In contrast, most of the water samples after the Holy Week period contained total coliforms (Table 3). In addition, fecal coliforms were detected in about $45 \%$ of total water samples after Holy Week (Table 4). Coliform 
presence is an excellent variable and widely utilized to establish water quality in terms of microbiological contamination [14]. In this particular study, it is apparent that human activity due to domestic tourism is contaminating this recreational aquatic area and is, therefore, a potential public health threat. In fact, according to the Health Department of the Chihuahua's State Government gastrointestinal illnesses represent the highest reported illness for visitors to Colina Lake during the Holy Week vacation period.

Table 2. Presence of total coliforms in the water of Colina Lake before Holy Week vacation period.

\begin{tabular}{|c|c|c|c|c|}
\hline SAMPLE & $\begin{array}{c}\text { DEPTH } \\
(\mathrm{m})\end{array}$ & $\mathrm{UFC} \mathrm{mL}^{-1}$ & $\mathrm{UFC} \mathbf{m L}^{-1}$ & $\begin{array}{l}\text { AVERAGE } \\
\text { UFC } \mathrm{mL}^{-1}\end{array}$ \\
\hline 12 & 0.30 & 6 & 0 & 3 \\
\hline 12 & 1.0 & 1 & 0 & 0.5 \\
\hline 13 & 0.30 & 8 & 0 & 4 \\
\hline 13 & 1.0 & 0 & 6 & 3 \\
\hline 19 & 0.30 & 1 & 0 & 0.5 \\
\hline 17 & 0.30 & 1 & 0 & 0.5 \\
\hline 15 & 0.30 & 0 & 2 & 1 \\
\hline 5 & 0.30 & 0 & 3 & 1.5 \\
\hline 18 & 1.0 & 0 & 4 & 2 \\
\hline 10 & 1.0 & 2 & 0 & 1 \\
\hline
\end{tabular}

From a total of 18 metals originally considered in the present study, $\mathrm{Ag}$ was not detected and the following metals were not statistically analyzed because of inconsistency of results: As, $\mathrm{Cd}, \mathrm{Fe}, \mathrm{Se}$ and $\mathrm{Mn}$. In general, the concentrations of $\mathrm{Al}, \mathrm{B}, \mathrm{Na}, \mathrm{Ni}$ and Se were statistically different according to factor A (sampling date-before and after) while the levels of $\mathrm{Cr}, \mathrm{Cu}, \mathrm{K}$ and $\mathrm{Mg}$ were statistically different due to factor A as well as factor B (depth) but no interaction was detected. The elements $\mathrm{Ca}$ and $\mathrm{Zn}$ were statistically different due to factor $\mathrm{A}$, factor B, and their interaction.

Table 3. Presence of total coliforms in the water of Colina Lake after Holy Week vacation period.

\begin{tabular}{|c|c|c|c|c|c|c|c|}
\hline \multirow[t]{2}{*}{ SAMPLE } & $\begin{array}{l}\text { UFC } \\
\mathbf{m L}^{-1} \\
\end{array}$ & $\begin{array}{l}\text { UFC } \\
\mathbf{m L}^{-1} \\
\end{array}$ & $\begin{array}{l}\text { MEAN } \\
\text { UFC } \mathbf{~ m L}^{-1}\end{array}$ & \multirow[t]{2}{*}{$\begin{array}{c}\text { SAMPL } \\
\text { E }\end{array}$} & $\begin{array}{l}\text { UFC } \\
\mathbf{m L}^{-1} \\
\end{array}$ & $\begin{array}{l}\text { UFC } \\
\mathbf{m L}^{-1} \\
\end{array}$ & 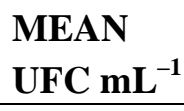 \\
\hline & \multicolumn{3}{|c|}{ DEPTH $(1.0 \mathrm{~m})$} & & \multicolumn{3}{|c|}{ DEPTH $(0.30 \mathrm{~m})$} \\
\hline 18 & 0 & 2 & 1 & 9 & 0 & 1 & 0.5 \\
\hline 5 & 1 & 0 & 0.5 & 17 & 0 & 3 & 1.5 \\
\hline 18 & 2 & 0 & 1 & 19 & 0 & 1 & 0.5 \\
\hline 14 & 0 & 2 & 1 & 2 & 0 & 3 & 1.5 \\
\hline 10 & 0 & 2 & 1 & 9 & 0 & 1 & 0.5 \\
\hline 10 & 0 & 2 & 1 & 15 & 0 & 2 & 1 \\
\hline 19 & 0 & 5 & 2.5 & 13 & 0 & 2 & 1 \\
\hline 19 & 0 & 12 & 6 & 20 & 0 & 2 & 1 \\
\hline
\end{tabular}


Table 3. Cont.

\begin{tabular}{|c|c|c|c|c|c|c|c|}
\hline \multirow[t]{2}{*}{ SAMPLE } & $\begin{array}{l}\text { UFC } \\
\mathbf{m L}^{-1}\end{array}$ & $\begin{array}{l}\mathrm{UFC} \\
\mathrm{mL}^{-1}\end{array}$ & $\begin{array}{l}\text { MEAN } \\
\text { UFC mL }^{-1}\end{array}$ & \multirow[t]{2}{*}{ SAMPLE } & $\begin{array}{l}\mathrm{UFC} \\
\mathrm{mL}^{-1}\end{array}$ & $\begin{array}{l}\text { UFC } \\
\mathrm{mL}^{-1}\end{array}$ & $\begin{array}{l}\text { MEAN } \\
\text { UFC mL }^{-1}\end{array}$ \\
\hline & \multicolumn{3}{|c|}{ DEPTH (1.0 m) } & & \multicolumn{3}{|c|}{ DEPTH $(0.30 \mathrm{~m})$} \\
\hline 8 & 0 & 4 & 2 & 6 & 0 & 7 & 3.5 \\
\hline 20 & 0 & 1 & 0.5 & 16 & 0 & 3 & 1.5 \\
\hline 9 & 0 & 6 & 3 & 19 & 0 & 1 & 0.5 \\
\hline 6 & 0 & 5 & 2.5 & 14 & 0 & 1 & 0.5 \\
\hline 5 & 0 & 5 & 2.5 & 8 & 0 & 8 & 4 \\
\hline 16 & 0 & 6 & 3 & 8 & 0 & 6 & 3 \\
\hline 16 & 0 & 6 & 3 & 6 & 0 & 3 & 1.5 \\
\hline 10 & 0 & 1 & 0.5 & 16 & 0 & 3 & 1.5 \\
\hline 3 & 0 & 5 & 2.5 & 4 & 0 & 2 & 1 \\
\hline 4 & 0 & 6 & 3 & 17 & 0 & 3 & 1.5 \\
\hline 6 & 0 & 4 & 2 & & & & \\
\hline 15 & 0 & 5 & 2.5 & & & & \\
\hline 3 & 0 & 1 & 0.5 & & & & \\
\hline 9 & 0 & 5 & 2.5 & & & & \\
\hline 8 & 0 & 5 & 2.5 & & & & \\
\hline 13 & 0 & 1 & 0.5 & & & & \\
\hline
\end{tabular}

Table 4. Presence of fecal coliform in the water of Colina Lake after the Holy Week vacation period.

\begin{tabular}{|c|c|c|c|c|}
\hline SAMPLE & DEPTH $(\mathrm{m})$ & UFC mL $\mathbf{m L}^{-1}$ & UFC $\mathbf{m L}^{-1}$ & AVERAGE UFC $\mathrm{mL}^{-1}$ \\
\hline 19 & 0.30 & 6 & 0 & 3 \\
\hline 19 & 0.30 & 3 & 0 & 1.5 \\
\hline 4 & 1.0 & 4 & 0 & 2 \\
\hline 9 & 1.0 & 2 & 0 & 1 \\
\hline 14 & 1.0 & 3 & 0 & 1.5 \\
\hline 15 & 1.0 & 1 & 0 & 0.5 \\
\hline 2 & 0.30 & 0 & 2 & 1 \\
\hline 6 & 1.0 & 3 & 0 & 1.5 \\
\hline 16 & 0.30 & 2 & 0 & 1 \\
\hline 16 & 0.30 & 3 & 0 & 1.5 \\
\hline 8 & 0.30 & 1 & 0 & 0.5 \\
\hline 15 & 0.30 & 1 & 0 & 0.5 \\
\hline 11 & 0.30 & 1 & 0 & 0.5 \\
\hline 18 & 1.0 & 1 & 0 & 0.5 \\
\hline 10 & 1.0 & 2 & 0 & 1 \\
\hline 10 & 1.0 & 5 & 0 & 2.5 \\
\hline 4 & 1.0 & 3 & 0 & 1.5 \\
\hline 10 & 0.30 & 3 & 0 & 1.5 \\
\hline
\end{tabular}

The ANOVA analysis detected differences for $\mathrm{Al}$ concentration due to date of sampling ( $\mathrm{P}<0.001)$; but no differences were noted for sample depth $(\mathrm{P}=0.591)$ nor their interaction $(\mathrm{P}=0.496)$. The mean $\mathrm{Al}$ level before the Holy Week vacation period was $0.67 \mathrm{ppm}$, while the mean 
concentration after this period was $0.76 \mathrm{ppm}$. Figure 2 shows this main effect and domestic tourism is probably contaminating this water reservoir with $\mathrm{Al}$.

Figure 2. Main effects plot for Al in Colina Lake water samples (Chihuahua, Mexico) before and after the 2010 Holy Week vacation period.

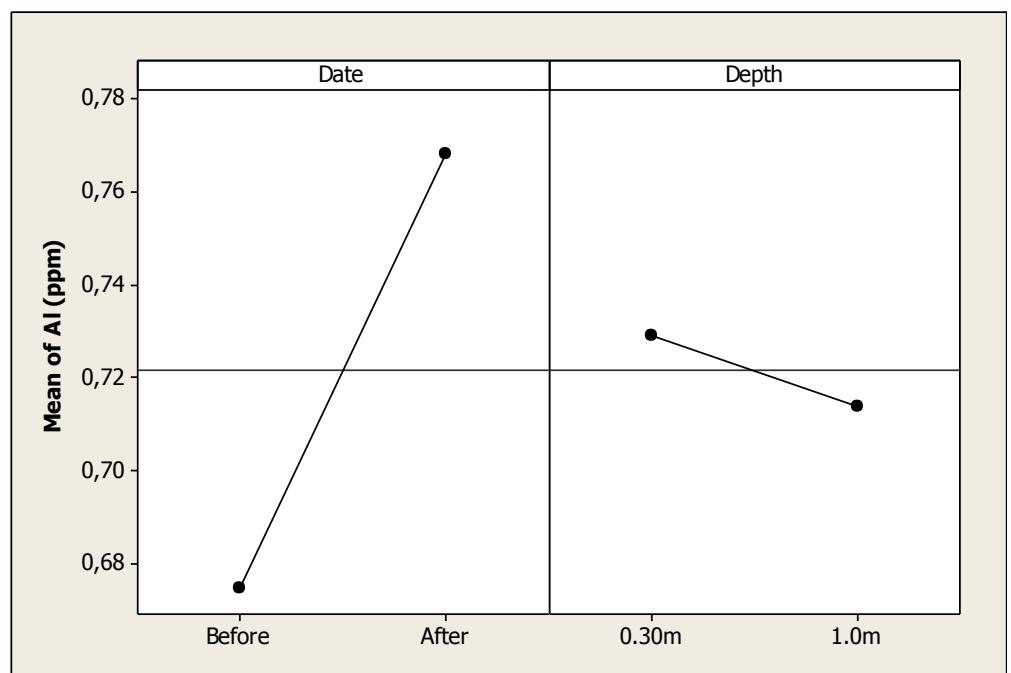

The results of this study concerning Al concentration are similar to those values reported by Holguin et al. [15], who found levels of $0.91 \mathrm{mgL}^{-1}$ in the lower part of the Conchos River. The $\mathrm{Al}$ levels are higher than the Maximum Permitted Level for potable water $\left(0.02 \mathrm{mg} \mathrm{L}^{-1}\right)$ established in the Mexican Norm of Ecological Criteria [16]. Unfortunately, there are no criteria concerning Al levels for recreational areas; however, it is evident that the $\mathrm{Al}$ concentration is higher after the Holy Week vacation period and, as a consequence, is affecting this recreational ecosystem. It can be hypothesized that garbage like beverage cans and similar objects is responsible for this effect.

Figure 3. Main effects plot for B in Colina Lake water samples (Chihuahua, Mexico) before and after the 2010 Holy Week vacation period.

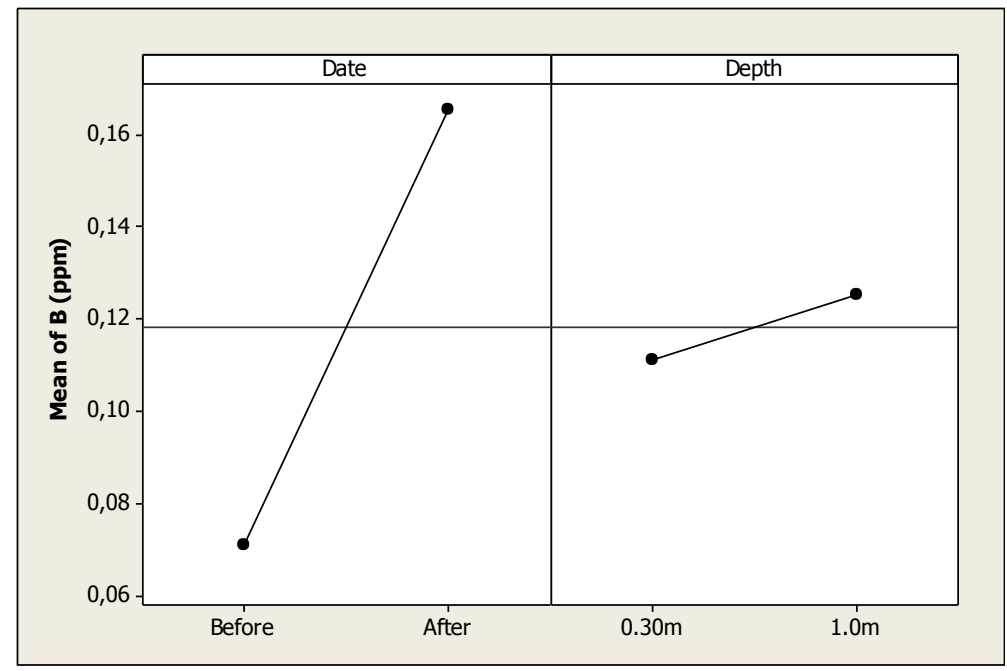

The ANOVA detected statistical differences in $\mathrm{B}$ levels as a function of sampling date $(\mathrm{P}<0.001)$ but no differences were noted for depth $(\mathrm{P}=0.168)$ or the interaction $(\mathrm{P}=0.843)$. This mean effect is 
shown in Figure 3, where a maximum B concentration with a mean of about $0.16 \mathrm{ppm}$ was observed after the Holy Week vacation period, in contrast with a mean of $0.07 \mathrm{ppm}$ noted before. Holguin et al. [15] reported levels of B of $0.518 \mathrm{mg} \mathrm{L}^{-1}$ in the lower part of the Conchos River in the same state, and Colina Lake is situated in the upper part of the Conchos River.

The ANOVA gave statistical differences in regard to Ca concentration for date $(\mathrm{P}<0.001)$, depth $(\mathrm{P}<0.001)$, and the interaction date-depth $(\mathrm{P}<0.004)$. This interaction effect is shown in Figure 4. Before the tourists visited in the Holy Week vacation period, the Ca concentration was about $41.2 \mathrm{ppm}$ at the $0.30 \mathrm{~m}$ depth, and this value increased slightly to about $42.7 \mathrm{ppm}$ at $1.0 \mathrm{~m}$ depth. Moreover, the Ca level after the Holy Week period increased at both depths. At $0.30 \mathrm{~m}$ depth the Ca concentration was $49.8 \mathrm{ppm}$ and then increased to $56.4 \mathrm{ppm}$ at $1.0 \mathrm{~m}$ depth. It is important to mention that there is no specific Maximum Permitted Level for this element in the Mexican norms. Any recreational lake can be classified according to the level of calcium carbonate; for instance, the Grand Lake in the United States of America was classified as moderately hard water lake [17]. Therefore, it is necessary to continue with the monitoring of this lake under study to know more about the different elements like $\mathrm{Ca}$ in the water at different seasons. Gutierrez et al. [18] found that Ca concentration increased in the lower part of the Conchos River, reaching levels of $120.23 \mathrm{mg} \mathrm{L}^{-1}$. These authors also showed that $\mathrm{Ca}$ levels increased in the rainy season, and it has to be pointed out that the present study was done in a different season.

Figure 4. Interaction plot for $\mathrm{Ca}$ in Colina Lake water samples (Chihuahua, Mexico) before and after the 2010 Holy Week vacation period.

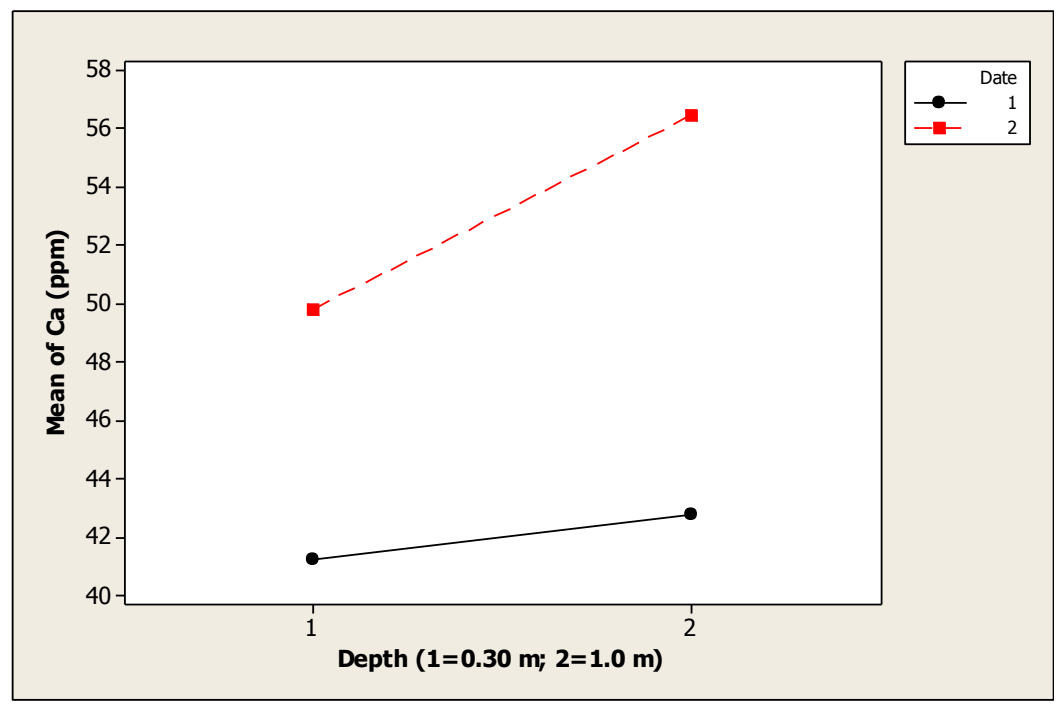

The $\mathrm{Cr}$ concentration was statistically different for date $(\mathrm{P}<0.000)$ and depth $(\mathrm{P}<0.000)$, but no differences were discovered for the interaction date-depth $(\mathrm{P}=0.554)$. Figure 5 shows the main factors effect where it is noted that the $\mathrm{Cr}$ level increased from $0.22 \mathrm{ppm}$ before the Holy Week vacation period to a level of $0.32 \mathrm{ppm}$ after this period. In addition, it is observed that this element rose from $0.25 \mathrm{ppm}$ at $0.30 \mathrm{~m}$ depth to $0.29 \mathrm{ppm}$ at $1.0 \mathrm{~m}$ depth. The results in this study are similar to the levels reported previously in the Conchos River during 2005 with a Cr concentration of $0.25 \mathrm{ppm}$ [19]. Nevertheless, in another study carried out in a tributary of the Conchos River, Gutierrez et al. [18] 
reported levels of $\mathrm{Cr}$ as higher as $0.014 \mathrm{mg} \mathrm{L}^{-1}$; thus, the level of the present study for Cr concentration is higher than previous studies in the same area.

Figure 5. Main effects plot for $\mathrm{Cr}$ in water samples of Colina Lake in Chihuahua, Mexico before and after the Holy Week vacation period.

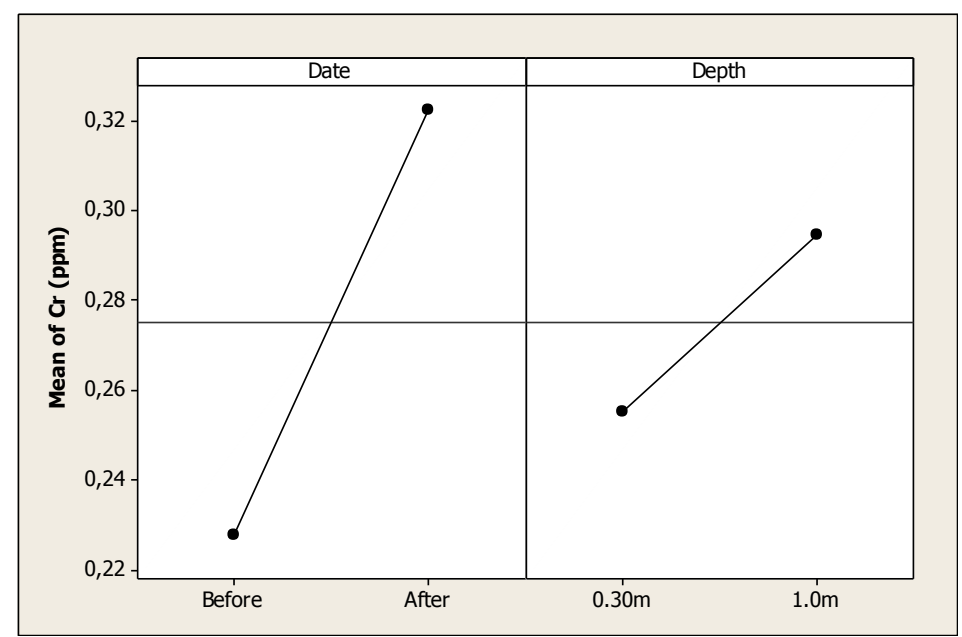

For $\mathrm{Cu}$, the ANOVA detected significant differences in date $(\mathrm{P}<0.001)$ and depth $(\mathrm{P}<0.001)$, but no differences were noted for the interaction $(\mathrm{P}=0.652)$. The main effect for this element is shown in Figure 6. It can be observed that the mean before the Holy Week vacation period was about $0.04 \mathrm{ppm}$ and this level increased to $0.06 \mathrm{ppm}$ after the vacation period. In addition, considering the depth factor, the mean at $0.30 \mathrm{~m}$ depth reached a concentration of $0.05 \mathrm{ppm}$, and at $1.0 \mathrm{~m}$ depth it increased to 0.06 ppm. $\mathrm{Cu}$ contamination of water has been considered in some areas to be the major potential threat to drinking water [20], although there exists a controversy concerning the maximum level of copper in water that represents a health risk [21]. A study carried out in 2004 on the Conchos River showed a maximum level of $\mathrm{Cu}$ of $0.057 \mathrm{mg} \mathrm{L}^{-1}$ in Parra (Chihuahua) which agrees with the findings of the study reported here [22].

Figure 6. Main effects plot for $\mathrm{Cu}$ in Colina Lake water samples (Chihuahua, Mexico) before and after the 2010 Holy Week vacation period.

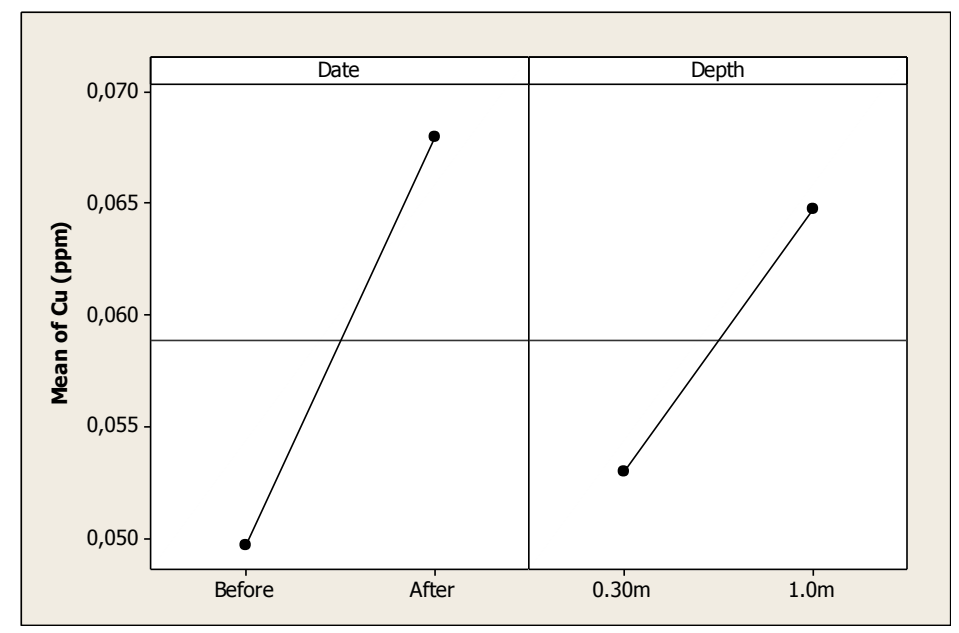


Potassium concentration was different as a function of sampling date $(\mathrm{P}<0.001)$ and sampling depth $(\mathrm{P}=0.019)$, and the interaction date-depth was not significant $(\mathrm{P}=0.936)$. Figure 7 shows the main factor effects for this element. It can be seen that before the Holy Week vacation period, the mean concentration was $4.7 \mathrm{ppm}$, and this level increased to $5.65 \mathrm{ppm}$ after this period. With respect to the depth factor, the mean at $0.30 \mathrm{~m}$ depth was $5.08 \mathrm{ppm}$ and $5.26 \mathrm{ppm}$ at $1.0 \mathrm{~m}$ depth. Even though a $\mathrm{K}$ concentration effect due to human presence in Colina Lake can be noted after the vacation period, this amount does not represent a health risk to local visitors.

Figure 7. Main effects plot for $\mathrm{K}$ in Colina Lake water samples (Chihuahua, Mexico) before and after the 2010 Holy Week vacation period.

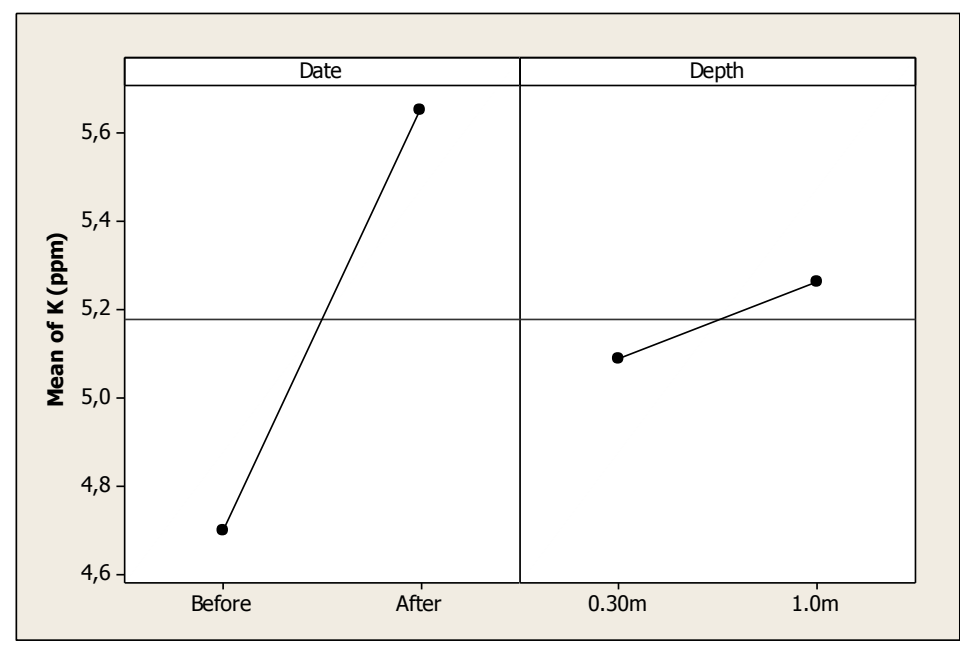

For $\mathrm{Mg}$, the ANOVA showed significant differences in date $(\mathrm{P}<0.001)$ and for the depth factor $(\mathrm{P}=0.007)$ but no differences were noted for the interaction $(\mathrm{P}=0.927)$. The $\mathrm{Mg}$ means before the Holy Week vacation was $3.81 \mathrm{ppm}$, and after this vacation period it increased to $4.54 \mathrm{ppm}$ (Figure 8). It can also be noted that the mean $\mathrm{Mg}$ at $0.30 \mathrm{~m}$ depth was $4.08 \mathrm{ppm}$, and then it increased to a level of $4.27 \mathrm{ppm}$ at $1.0 \mathrm{~m}$ depth. The $\mathrm{Mg}$ levels reported in this study are lower than those reported previously by Rubio-Arias [22] in a study conducted on six tributaries of the Conchos River.

Figure 8. Main effects plot for $\mathrm{Mg}$ in Colina Lake water samples (Chihuahua, Mexico) before and after the 2010 Holy Week vacation period.

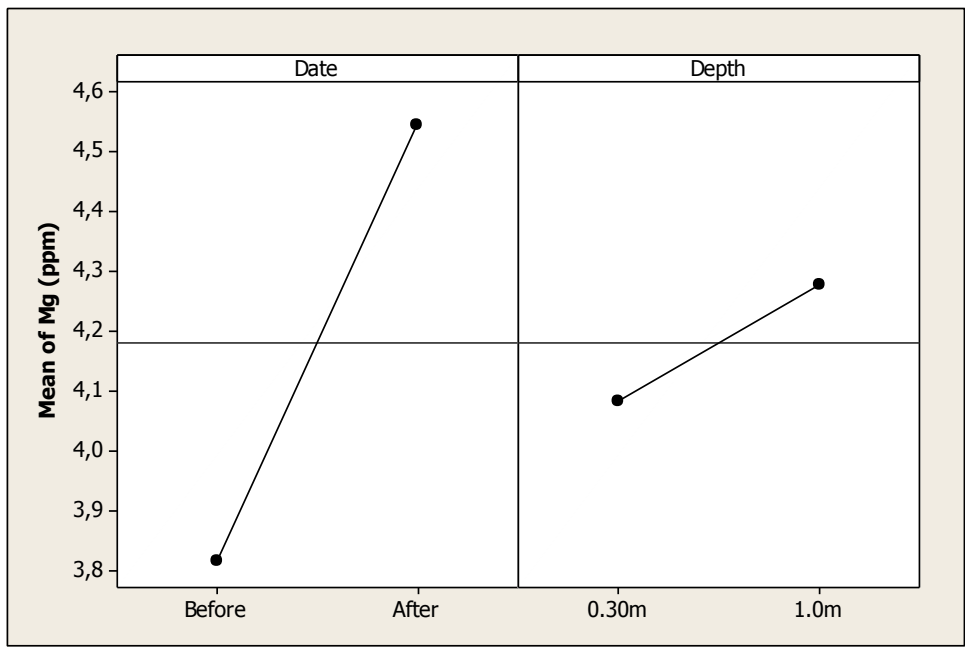


Sodium concentrations were different as a function of date $(\mathrm{P}<0.001)$, but no differences were noted for factor depth $(\mathrm{P}=0.065)$ nor for the interaction $(\mathrm{P}=0.928)$. Figure 9 shows this main effect, and it is noted that before the domestic tourism was present in Colina Lake the amount of Na was about $9.86 \mathrm{ppm}$. This element increased to $15.70 \mathrm{ppm}$ after the visitors' stay at the recreational lake. The levels reported in this study for Na were lower than those reported by Holguin et al. [15].

Figure 9. Main effects plot for $\mathrm{Na}$ in Colina Lake water samples (Chihuahua, Mexico) before and after the 2010 Holy Week vacation period.

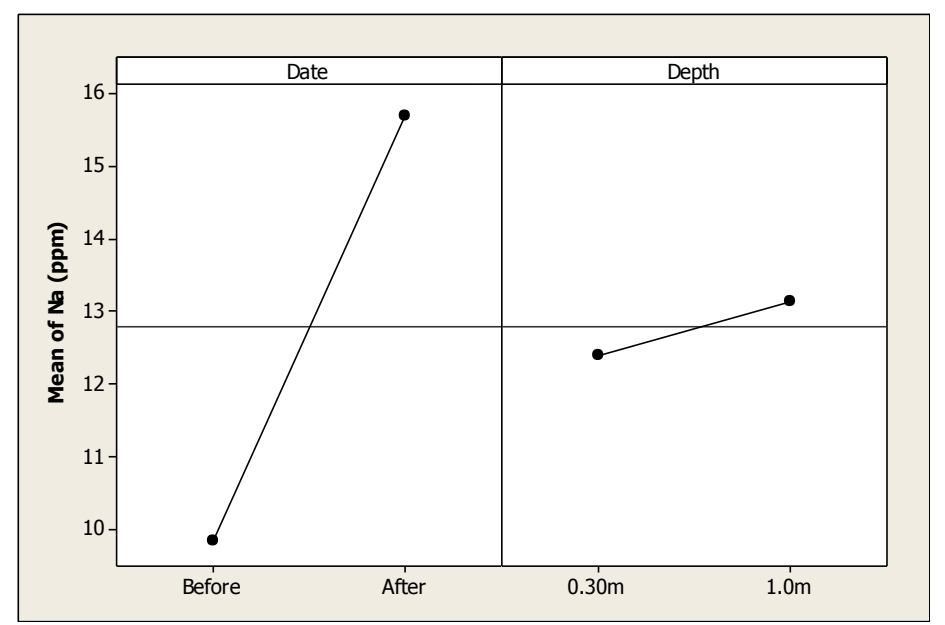

The Ni concentration was statistically different for date $(\mathrm{P}<0.000)$, but no differences were observed for sampling depth ( $\mathrm{P}=0.433)$, nor for the date-depth interaction ( $\mathrm{P}=0.041)$. This effect is shown in Figure 10 where the mean of Ni before the Holy Week vacation period was $1.01 \mathrm{ppm}$, and this element increased to $1.77 \mathrm{ppm}$ after the Holy Week vacation period. The values reported in this study relative to element $\mathrm{Ni}$ are higher than previously reported where it was found at $0.47 \mathrm{mg} \mathrm{L}^{-1}$ as the most contaminated location [19]. In addition, Ni values are higher than the findings of Holguin et al. [15] and Gutierrez et al. [18] that were determined in the same watershed. It is important to note that the concentration of this element is higher than those specified as maximum permitted levels for water for agricultural and animal production uses in the Mexican Norm.

Figure 10. Main effects plot for $\mathrm{Ni}$ in Colina Lake water samples (Chihuahua, Mexico) before and after the 2010 Holy Week vacation period.

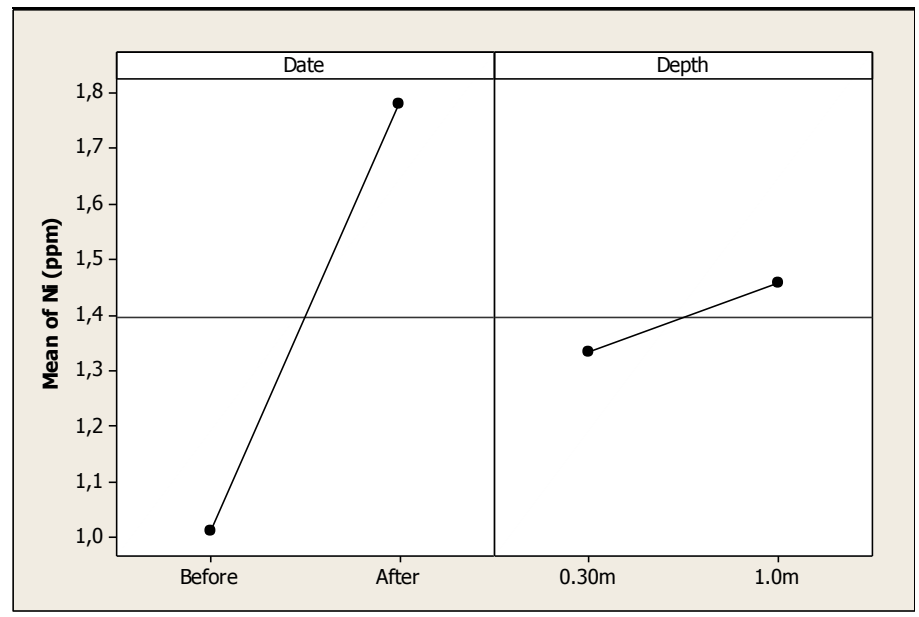


There were no statistical differences for $\mathrm{Pb}$ concentrations for date $(\mathrm{P}=0.175)$ and depth $(\mathrm{P}=0.495)$, but the interaction was slightly significant $(\mathrm{P}<0.01)$. The mean before the Holy Week vacation period was $0.018 \mathrm{ppm}$ at $0.30 \mathrm{~m}$ depth, and this level changed to $0.011 \mathrm{ppm}$ at $1.0 \mathrm{~m}$ depth (Figure 11). After the vacation period the mean at $0.30 \mathrm{~m}$ was $0.015 \mathrm{ppm}$, and at $1.0 \mathrm{~m}$ depth the mean was $0.019 \mathrm{ppm}$.

Figure 11. Interaction plot for $\mathrm{Pb}$ in Colina Lake water samples (Chihuahua, Mexico) before and after the 2010 Holy Week vacation period.

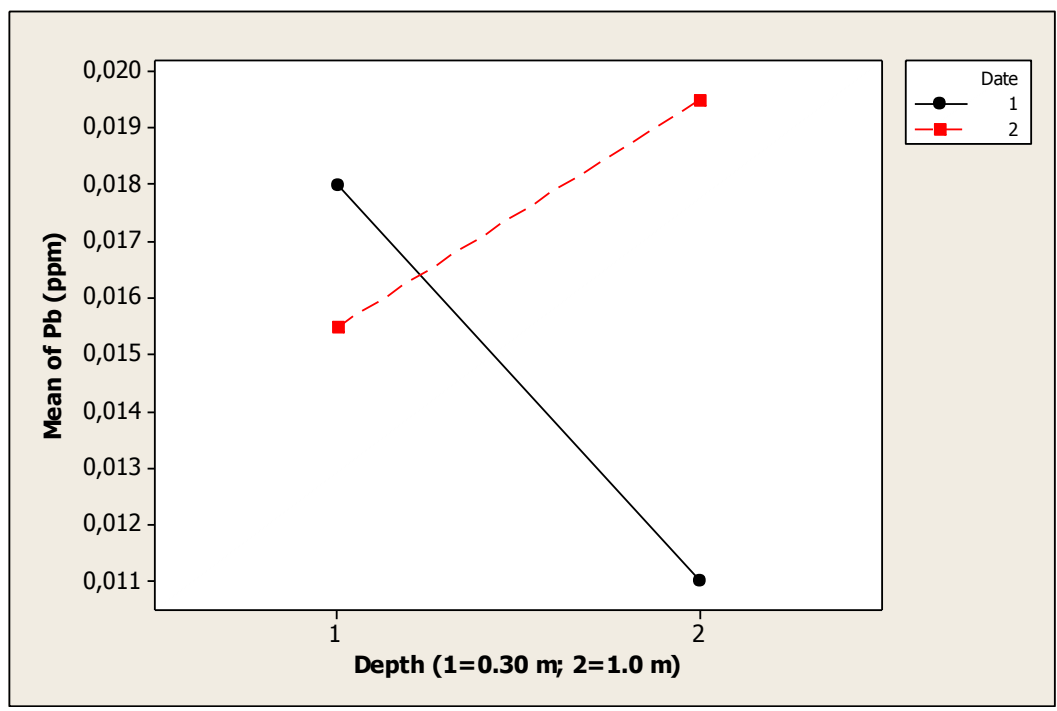

The Si concentration was statistically different for sampling date $(\mathrm{P}<0.001)$, but no differences were noted for depth $(\mathrm{P}=0.333)$. The date-depth interaction was significant $(\mathrm{P}=0.01)$. Figure 12 shows this interaction effect, where it is noted that the mean of $\mathrm{Si}$ at $0.30 \mathrm{~m}$ depth, before the Holy Week vacation period, was about $5.9 \mathrm{ppm}$, and then, this level decreased to $4.9 \mathrm{ppm}$ at $1.0 \mathrm{~m}$ depth. With respect to after Holy Week period, the Si level was about $8.51 \mathrm{ppm}$ at $0.30 \mathrm{~m}$ depth, and then increased to a level of $11.25 \mathrm{ppm}$ at $1.0 \mathrm{~m}$ depth.

Figure 12. Interaction plot for $\mathrm{Si}$ in Colina Lake water samples (Chihuahua, Mexico) before and after the 2010 Holy Week vacation period.

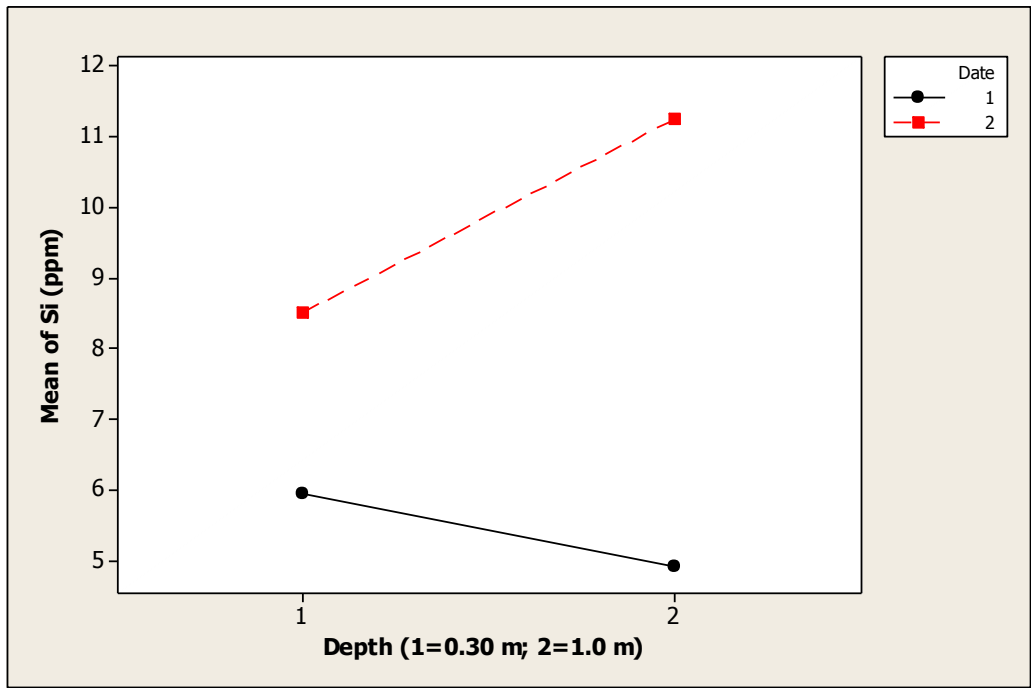


The $\mathrm{Zn}$ concentration was different for sampling date $(\mathrm{P}<0.001)$ and depth $(\mathrm{P}=0.01)$, and the interaction was not significant $(\mathrm{P}=0.12)$. Figure 13 shows the main factor effects where it can be noted that the mean of $\mathrm{Zn}$ before the Holy Week vacation period was $0.03 \mathrm{ppm}$, and then after this period the concentration increased to $0.16 \mathrm{ppm}$. Also, the mean of this element before the vacation period was $0.06 \mathrm{ppm}$ at a depth of $0.30 \mathrm{~m}$, and this value increased to $0.14 \mathrm{ppm}$ at $1.0 \mathrm{~m}$ depth after the vacation period.

Figure 13. Main effects plot for $\mathrm{Zn}$ in Colina Lake water samples (Chihuahua, Mexico) before and after the 2010 Holy Week vacation period.

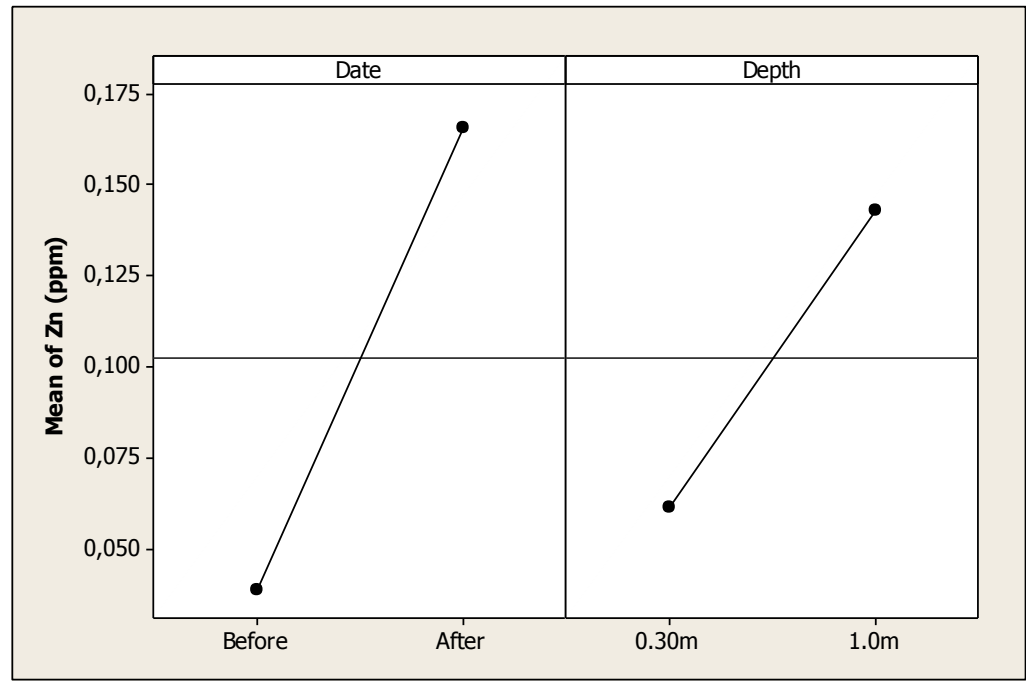

\section{Conclusions}

Levels of most heavy metals concentration in this study were higher after the Holy Week vacation period in comparison with the concentration of these elements before the Holy Week vacation period. These results are of practical importance because Colina Lake is obviously being affected by the domestic tourism. Moreover, these results represent a red flag for the authorities as well as for the communities and stakeholders of the area who depend of this recreational area.

\section{Acknowledgements}

We are deeply grateful with the Faculty of Chemistry of the Autonomous University of Chihuahua for lab facilities to evaluate total and fecal coliforms. We profoundly express our gratitude to the Jackson State University, Mississippi, USA for the invitation to present this paper as an oral conference in the 2010's Seventh International Symposium on Recent Advances in Environemntal Health Research.

\section{References and Notes}

1. Kastelein, B. Money over nature: In Fox administration, business interests trump environmental concerns on sustainable development. (tourism development)(Column). Business Mexico, 1 May 2004, volume 14, p. 32(4). 
2. Del Angel, E.; Rubio, A.H.; Frias, D.M.; Laguna, D. Health risks due to the presence of lead $(\mathrm{Pb})$ and copper $(\mathrm{Cu})$ in a coastal area of Tabasco, Mexico. In Environmental Health Risk V; Brebbia, C.A., Ed.; WIT: Boston, MA, USA, 2009; pp. 125-132.

3. Latin American Data Base/Latin American Institute. Severe contamination reported at several Mexican beaches. SourceMex Economic News \& Analysis on Mexico, 19 February 2003.

4. Walder, G. Toursim development and environmental management in Nepal: A study of Sagarmatha National Park and Anarpuna, Conservation Area Project with Special Reference to Upper Mustang. MSc Thesis, Bournemouth University: Bournemouth, UK, 2000.

5. Department of Business, Gobierno del Estado de Chihuahua, Mexico. Estadisticas de Turismo Local; Gobierno del Estado de Chihuahua: Chihuahua, Mexico, 2009.

6. Instituto Nacional de Estadistica Geografia e Historia en Mexico. Libro para el estado de Chihuahua, Mexico; INEGI: Aguascalientes, Mexico, 2006; pp. 340-345.

7. Norma Mexicana NMX-AA-115-SCFI-2000. Analisis de agua-Criterios generales para el control de la calidad de resultados analíticos; Secretaria de Economia: Mexico City, Mexico, 2000.

8. Norma Mexicana NMX-AA-007-SCFI-2000. Analisis de agua-Determinación de la temperatura en aguas naturales, residuales y residuales tratadas-Metodo de prueba; Diario Oficial de la Federacion del 23 de julio: Mexico City, Mexico, 1980.

9. Norma Mexicana NMX-AA-008-SCFI-2000. Analisis de agua-Determinacion del pH-Metodo de prueba; Diario Oficial de la Federacion del 25 de marzo: Mexico City, Mexico, 1980.

10. Norma Mexicana NMX-AA-093-SCFI-2000. Analisis de agua-Determinación de la conductividad electrolítica-Metodo de prueba; Secretaria de Comercio y Fomento Industrial CDU.631.879: Mexico City, Mexico, 2000.

11. Norma Mexicana NMX-AA-051-SCFI-1981. Analisis de agua-Determinación de metales, metodo espectrofotométrico de absorción atómica; Diario Oficial de la Federacion del 22 de febrero: Mexico City, Mexico, 1982.

12. McFeters, G.; Kippin, J.; LeChevallier, M. Injured coliforms in drinking water. Appl. Environ. Microbiol. 1986, 51, 1-5.

13. Norma Mexicana NOM-112-SSA1-1994. Bienes y servicios. Determinación de bacterias coliformes. Técnica del número más probable; Secretaría de Salud: Mexico City, Mexico, 1994.

14. U.S. Environmental Protection Agency. Improved Enumeration Methods for the Recreational Water Quality Indicators: Enterococci and Escherichia coli (EPA/821/R-97004); EPA Office of Science and Technology: Washington, DC, USA, 2000.

15. Holguin, C.; Rubio, A.H.; Olave, M.E.; Saucedo, R.; Gutierrez, M.; Bautista, R. Calidad del agua del rio Conchos en la región de Ojinaga, Chihuahua; parámetros fisicoquímicos, metales y metaloides. Universidad y C. 2006, 22, 51-64.

16. CECA. Criterios Ecologicos de Calidad de Agua CE-CCA-001-1989. Diario Oficial de la Federacion el 13 de diciembre de 1989; Secretaria de Desarrollo Urbano y Ecologia: Mexico City, Mexico, 1989.

17. Caneday, L.; Brandon, N. Can we go to the lake? A case for the future. National Recreation and Park Association: Ashburn, VA, USA, 1996; Available online: http://www.highbeam.com/doc/ 1G1-18605298.html (accessed on 1 November 2010). 
18. Gutierrez, R.; Rubio-Arias, H.; Quintana, R.; Ortega, J.A.; Gutierrez, M. Heavy metals in water of the San Pedro River in Chihuahua, Mexico and its potential health risk. IJERPH 2008, 5, 91-98.

19. Rubio-Arias, H.; Quintana, C.; Jimenez-Castro, J.; Quintana, R.; Gutierrez, M. Contamination of the Conchos River in Mexico: Does it pose a health risk to local residents. IJERPH 2010, 7 , 2071-2084.

20. Hong, K.; Yongsung, C. Estimating willingness to pay for reduced copper contamination in Southwestern Minnesota. J. Agr. Resour. Econ. 2002, 27, 250-263; Available online: http://www.highbeam.com/doc/1P3-290039061.html (accessed on 2 November 2010).

21. NRC report oil copper in drinking water (brief article). National Environmental Health Association: Denver, CO, USA, 2000; Available online: http://www.highbeam.com/doc/1G164566707.html (accessed on 2 November 2010).

22. Rubio-Arias, H.; Wood, K.; Alanis, H.E. Water pollution in the Rio Conchos of Northern Mexico. In Development and Application of Computer Techniques to Environmental Studies; Latini, X.G., Passerini, G., Brebbia, C.A., Eds.; WitPress: Southampton, UK, 2004; pp. 167-176.

(C) 2011 by the authors; licensee MDPI, Basel, Switzerland. This article is an open access article distributed under the terms and conditions of the Creative Commons Attribution license (http://creativecommons.org/licenses/by/3.0/). 